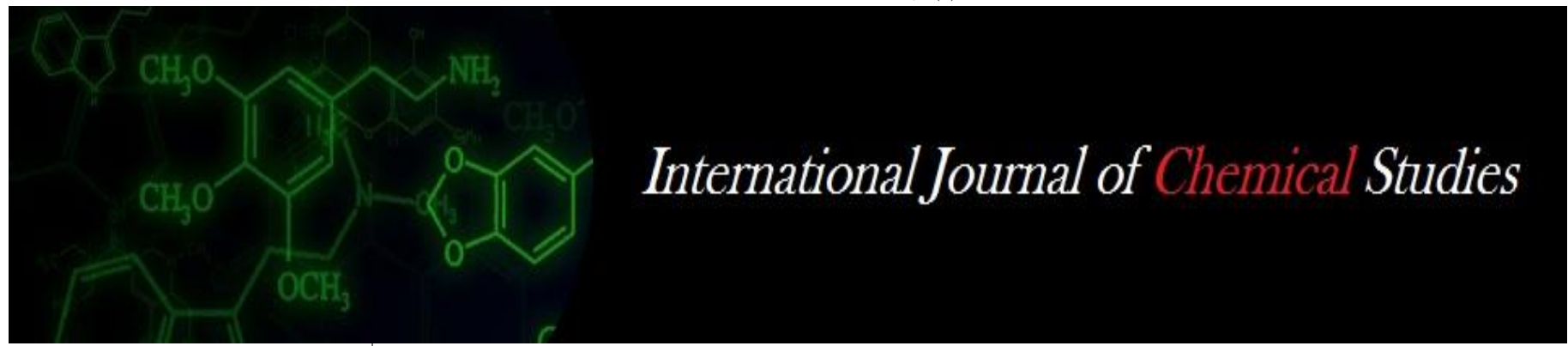

P-ISSN: 2349-8528

E-ISSN: 2321-4902

IJCS 2020; 8(1): 1869-1873

(C) 2020 IJCS

Received: 28-11-2019

Accepted: 30-12-2019

SM Choudhary

Department of Horticulture,

Mahatma Phule Krishi

Vidyapeeth, Rahuri,

Maharashtra, India

\section{AM Musmade}

Department of Horticulture,

Mahatma Phule Krishi

Vidyapeeth, Rahuri,

Maharashtra, India

\section{SS Kulkarni}

Department of Horticulture,

Mahatma Phule Krishi

Vidyapeeth, Rahuri,

Maharashtra, India

\section{SP Pawaskar}

Department of Horticulture,

Mahatma Phule Krishi

Vidyapeeth, Rahuri,

Maharashtra, India

VA Bodkhe

Department of Horticulture,

Mahatma Phule Krishi

Vidyapeeth, Rahuri,

Maharashtra, India

\section{R Kumar}

Department of Horticulture, Mahatma Phule Krishi

Vidyapeeth, Rahuri,

Maharashtra, India

Corresponding Author: SM Choudhary

Department of Horticulture,

Mahatma Phule Krishi

Vidyapeeth, Rahuri,

Maharashtra, India

\section{Effect of pruning time on bio-chemical parameters of guava (Psidium guajava $\mathbf{L}$.) genotypes}

\author{
SM Choudhary, AM Musmade, SS Kulkarni, SP Pawaskar, VA Bodkhe \\ and R Kumar
}

DOI: https://doi.org/10.22271/chemi.2020.v8.i1aa.8537

\begin{abstract}
The research was carried out at the Instructional-cum-Research Farm, Department of Horticulture, MPKV, Rahuri during the year 2016 and 2017. The present investigations were conducted on seven different genotypes namely RHR-Guv-58, RHR-Guv-60, RHR-Guv-14, RHR-Guv-16, RHR-Guv-3, RHR-Guv-6 and Sardar with five pruning time i.e. $15^{\text {th }}$ May, $15^{\text {th }}$ June, $15^{\text {th }}$ July, $15^{\text {th }}$ August, $15^{\text {th }}$ Sept. and no pruning (control). The experiment was laid out in Factorial Randomized Block Design with forty two treatments and was replicated two times. The results revealed that the maximum TSS of fruit (12.33 ${ }^{0}$ Brix) was observed in Sardar. The maximum total sugars $(8.08 \%)$, reducing sugars $(5.07 \%)$, sugar: acid ratio (22.33) with minimum acidity $(0.36 \%)$ were recorded in $\mathrm{G}_{3}$ (RHR-Guv-58) genotype. The maximum ascorbic acid of fruit $(208.33 \mathrm{mg} / 100 \mathrm{~g})$ and shelf life of fruit (9.75 days) was recorded in $\mathrm{G}_{4}$ (RHR-Guv-14) genotype. Fruit quality of genotypes was remained more or less similar irrespective to pruning time.
\end{abstract}

Keywords: Guava, pruning time, quality, genotypes, shelf-life

\section{Introduction}

Guava (Psidium guajava L.) is belonging to Myrtaceae family popularly known as "poor man's fruit" or "apple of tropics" (Singh, 2013) ${ }^{[18]}$. It is native to tropical America stretching from Mexico to Peru and was introduced in India by the Portuguese during $17^{\text {th }}$ century (Menzel, 1985) ${ }^{[8]}$. Guava is the fourth most important fruit crop in India after Mango, Banana and Citrus (Ray, 2002) ${ }^{[15]}$ and is popular due to its round year availability, rich nutritional and medicinal value and affordable price, suitability for transportation, handling and consumer preference. It exceeds most other fruits in productivity, hardiness, adoptability and vitamin $\mathrm{C}$ content (Singh and Singh, 2001) ${ }^{[20]}$.

Guava is often marketed as "super fruit", being rich in vitamins ' $A$ ' and ' $C$ ' with seeds that are rich in omega-3, omega-6 polyun saturated fatty acids and especially dietary fiber (Nimisha, et al., 2013) ${ }^{[10]}$. The development of colour, sweetness, aroma and vitamin $\mathrm{C}$ are dependent on low temperature and dry atmosphere, owing to this fact the quality of winter season fruits is better compared to that rainy and spring seasons. It is a popular fruit of India due to its delightful taste, flavour and easy availability. Guava is used for preparation of jams, jellies, juices, cakes, pies, ice-cream, milk shakes, sauces, butter, cheese, marmalade, chutney, relish, pickle, puree, beverages, ethanol, wine, animal feed, baby food, soft-drinks, as source of pectin, etc (Nagar et al., 2017) ${ }^{[9]}$. Guava trees bear terminally, that's why pruning influences more sprouting of shoots, flowering, fruiting and consequently increase in the yield and quality of guava (Dubey et al., 2002) ${ }^{[4]}$. Keeping in a view the above facts, it is felt to undertake the research work on effect of pruning time on bio-chemical parameters of guava (Psidium guajava L.) genotypes.

\section{Material and methods}

An experiment was carried out with an objective to study quality of guava genotypes during the year 2016 and 2017 at the Instructional-cum-Research Farm, Department of Horticulture, present investigations were conducted on seven different genotypes namely $\operatorname{Sardar}\left(\mathrm{G}_{1}\right)$, 
Mahatma Phule Krishi Vidyapeeth, Rahuri. The RHR-Guv-58 $\left(\mathrm{G}_{2}\right)$, RHR-Guv-60 (G $\left.\mathrm{G}_{3}\right)$, RHR-Guv-14 $\left(\mathrm{G}_{4}\right)$, RHR-Guv-16 $\left(\mathrm{G}_{5}\right)$, RHR-Guv-3 $\left(\mathrm{G}_{6}\right)$ and RHR-Guv-6 $\left(\mathrm{G}_{7}\right)$ with five pruning time i.e. $15^{\text {th }}$ May $\left(\mathrm{P}_{1}\right), 15^{\text {th }}$ June $\left(\mathrm{P}_{2}\right), 15^{\text {th }}$ July $\left(\mathrm{P}_{3}\right), 15^{\text {th }}$ August $\left(\mathrm{P}_{4}\right), 15^{\text {th }}$ Sept $\left(\mathrm{P}_{5}\right)$ and no pruning (control) $\left(\mathrm{P}_{6}\right)$. The genotypes were pruned 75 per cent of current season growth of guava plants at different times to understand influence on quality. The experiment was laid out in Factorial Randomized Block Design with forty two treatments and was replicated two times. Observations on quality parameters were recorded. Guava fruits were analyzed at 3/4 ripening stage for quality. Five fruits from each treatment per replication were selected randomly and halved by Knife which was further pulped through a mixer. Eventually, homogenized fruit pulp sample was taken for biochemical analysis. Total soluble solids of fruits were determined with the help of a hand refractometer (Erma Tokyo- $\mathrm{A}^{0} 32$ ), total sugars, reducing sugars and nonreducing sugars of fruits were determined by volumetric method (Lane and Eynon, 1960) ${ }^{[6]}$ ascorbic acid of fruits were estimated by direct titration method using 2-6 dichlorophenol indophenol dye (AOAC, 1990) [6] and also determined with the help of a NIR machine. The statistical analysis of the data for both the experiment was done as per the standard procedure (Panse and Sukhatme, 1985) ${ }^{[12]}$.

\section{Results and discussion}

\section{T.S.S. ( ${ }^{0}$ Brix) of fruit}

The data on T.S.S. of fruit are displayed in Table 1. The maximum T.S.S. of fruit $\left(11.43{ }^{0}\right.$ Brix $)$ was recorded in $\mathrm{P}_{1}$ treatment, which was followed by $\mathrm{P}_{6}$ treatment $\left(11.34{ }^{0} \mathrm{Brix}\right)$ and minimum in $\mathrm{P}_{2}$ treatment $\left(11.16{ }^{\circ} \mathrm{Brix}\right)$ in pooled analysis of pruning time. Effect of various genotypes was found to be significant for the T.S.S. of fruit of pooled results. The significantly maximum T.S.S. of fruit $\left(12.23{ }^{0} \mathrm{Brix}\right)$ was observed in $\mathrm{G}_{1}$ genotype and the minimum (11.04 ${ }^{0}$ Brix) in $\mathrm{G}_{3}$ genotype. Result of conducted experiment showed that, time of pruning does not affect too much on T.S.S. but various genotypes get affected by pruning in that maximum T.S.S. was recorded in $\mathrm{G}_{1}$ (Sardar) as compared to others genotypes. This is due to the effect of pruning on plants, attributed to lower leaves/ fruit ratio and better availability of carbohydrates reserved stored in pruned shoots at a correct time and characteristics of the genotype. Similar results regarding the effect of pruning time on T.S.S of fruit were recorded by Sheikh and Hulmani (1996) ${ }^{[16]}$, Singh and Dhaliwal (2004) ${ }^{[19]}$ and Ali and Abdel-Hameed (2014) ${ }^{[1]}$ in guava.

Table 1: Effect of pruning time and genotypes on T.S.S. $\left({ }^{0} \mathrm{Brix}\right)$ of fruit

\begin{tabular}{|c|c|c|c|c|c|c|c|c|}
\hline \multirow{3}{*}{$\begin{array}{c}\text { Treatments } \\
\begin{array}{c}\text { Pruning } \\
\text { time }\end{array} \\
\end{array}$} & \multirow{2}{*}{\multicolumn{8}{|c|}{$\begin{array}{c}\text { T.S.S. of fruit (Pooled data of } 2 \text { years- } 2016 \& 2017) \\
\text { Guava genotypes }\end{array}$}} \\
\hline & & & & & & & & \\
\hline & $\mathrm{G}_{1}$ & $\mathrm{G}_{2}$ & $\mathrm{G}_{3}$ & $\mathrm{G}_{4}$ & $\mathrm{G}_{5}$ & $\mathrm{G}_{6}$ & $\mathrm{G}_{7}$ & Mean \\
\hline $\mathrm{P}_{1}$ & 12.46 & 11.17 & 11.14 & 11.31 & 11.34 & 11.29 & 11.30 & 11.43 \\
\hline $\mathrm{P}_{2}$ & 11.82 & 11.00 & 11.00 & 11.12 & 11.12 & 11.04 & 11.00 & 11.16 \\
\hline $\mathrm{P}_{3}$ & 12.13 & 11.02 & 11.00 & 11.05 & 11.10 & 11.09 & 11.06 & 11.21 \\
\hline $\mathrm{P}_{4}$ & 12.23 & 11.09 & 11.02 & 11.14 & 11.37 & 11.02 & 11.06 & 11.28 \\
\hline $\mathrm{P}_{5}$ & 12.34 & 11.07 & 11.03 & 11.14 & 11.09 & 11.02 & 11.26 & 11.28 \\
\hline $\mathrm{P}_{6}($ Control $)$ & 12.41 & 11.09 & 11.07 & 11.22 & 11.25 & 11.17 & 11.20 & 11.34 \\
\hline & 12.23 & 11.07 & 11.04 & 11.16 & 11.21 & 11.10 & 11.14 & 11.28 \\
\hline \multicolumn{2}{|c|}{ Year 2016 \& 2017} & \multicolumn{2}{|c|}{ Pruning time } & \multicolumn{2}{|c|}{$\begin{array}{c}\text { Guava } \\
\text { genotypes }\end{array}$} & \multicolumn{3}{|c|}{ Interaction $(\mathrm{P} \times \mathrm{G})$} \\
\hline \multicolumn{2}{|c|}{$\mathrm{SE}(\mathrm{m}) \pm$} & \multicolumn{2}{|c|}{0.10} & \multicolumn{2}{|c|}{0.11} & \multicolumn{3}{|c|}{0.27} \\
\hline \multicolumn{2}{|c|}{ CD 5\% } & \multicolumn{2}{|c|}{ NS } & \multicolumn{2}{|c|}{0.30} & \multicolumn{3}{|c|}{ NS } \\
\hline
\end{tabular}

\section{Total sugars $(\%)$ of fruit}

The data in Table 2 presented that, the statistically significant differences were recorded for the total sugars of fruit due to the various treatments of pruning time. The maximum total sugars of fruit were recorded in $\mathrm{P}_{1}$ treatment $(8.04 \%)$, which was at par with $\mathrm{P}_{2}$ treatment $(7.88 \%)$ and minimum in $\mathrm{P}_{5}$ treatment $(7.61 \%)$. Effect of different genotypes pooled results indicated that, maximum total sugars of fruit $(8.08 \%)$ were noted in $\mathrm{G}_{3}$ genotype, which was at par with $\mathrm{G}_{6}$ genotype $(7.97 \%)$, while the minimum $(7.51 \%)$ in $\mathrm{G}_{1}$ genotype. The interaction between different time of pruning and various genotypes the maximum total sugars of fruit $(8.38$ $\%$ ) were noticed in $\mathrm{P}_{1} \mathrm{G}_{3}$ and the minimum $(7.31 \%)$ in $\mathrm{P}_{5} \mathrm{G}_{1}$ treatment combination. Present results reported that, improvement was observed in quality of guava fruit of pruned plants compared to control plants. This might be due to increase nutrient uptake by the trees and consequently more synthesis of carbohydrates and other metabolites and their translocation to the fruits. The similar results are conformity with Sing et al., (2005) and Kumar and Rattanpal (2010) [5] reported that better quality of fruits observed in pruned guava plants compared to control plants.

Table 2: Effect of pruning time and genotypes on total sugars (\%) of fruit

\begin{tabular}{|c|c|c|c|c|c|c|c|c|}
\hline \multirow{3}{*}{$\begin{array}{c}\text { Treatments } \\
\begin{array}{c}\text { Pruning } \\
\text { time }\end{array}\end{array}$} & \multicolumn{8}{|c|}{\begin{tabular}{|c|} 
Total sugars of fruit (Pooled data of 2 years- $2016 \&$ \\
2017)
\end{tabular}} \\
\hline & \multicolumn{8}{|c|}{\begin{tabular}{|c|} 
Guava genotypes \\
\end{tabular}} \\
\hline & $\mathrm{G}_{1}$ & $\mathrm{G}_{2}$ & $\mathrm{G}_{3}$ & $\mathrm{G}_{4}$ & $\mathrm{G}_{5}$ & $\mathrm{G}_{6}$ & $\mathrm{G}_{7}$ & Mean \\
\hline $\mathrm{P}_{1}$ & 7.75 & 7.90 & 8.38 & 8.01 & 7.98 & 8.27 & 8.02 & 8.04 \\
\hline $\mathrm{P}_{2}$ & 7.63 & 7.65 & & & & & 7.85 & \\
\hline $\mathrm{P}_{3}$ & 7.33 & 7.52 & 7.96 & 7.7 & 7.6 & 7.90 & 7.62 & 7.66 \\
\hline $\mathrm{P}_{4}$ & 7.50 & 7.65 & 7.83 & 7.77 & 7.72 & 7.67 & 7.39 & 7.65 \\
\hline $\mathrm{P}_{5}$ & 7.31 & 7.61 & 7.94 & 7.77 & 7.5 & 7.73 & 7.42 & 7.61 \\
\hline $\mathrm{P}_{6}($ Control $)$ & 7.53 & 7.68 & 8.1 & 7.8 & 7.7 & 8.10 & 7.82 & 7.83 \\
\hline Mean & 7.51 & 7.67 & 8.08 & 7.82 & 7.73 & 7.97 & 7.69 & 7.78 \\
\hline \multicolumn{2}{|c|}{ Year 2016 \& 2017} & \multicolumn{2}{|c|}{ Pruning time } & \multicolumn{2}{|c|}{$\begin{array}{l}\text { Guava } \\
\text { genotypes }\end{array}$} & \multicolumn{3}{|c|}{ Interaction $(\mathrm{P} \times \mathrm{G})$} \\
\hline \multicolumn{2}{|c|}{$\mathrm{SE}(\mathrm{m}) \pm$} & \multicolumn{2}{|c|}{0.06} & \multicolumn{2}{|c|}{0.06} & \multicolumn{3}{|c|}{0.16} \\
\hline \multicolumn{2}{|l|}{ CD 5\% } & \multicolumn{2}{|c|}{016} & & & \multicolumn{3}{|c|}{ NS } \\
\hline
\end{tabular}

\section{Reducing sugars $(\%)$ of fruit}

The data on reducing sugars of fruit have been presented in Table 3. Effect of different pruning time was found significant in pooled results, i.e. maximum (4.99\%) in $\mathrm{P}_{1}$ treatment and lowest $(4.37 \%)$ in $\mathrm{P}_{5}$ treatment. The highest reducing sugars of fruit $(5.07 \%)$ were recorded in $\mathrm{G}_{3}$ genotype and minimum $(4.28 \%)$ in $\mathrm{G}_{1}$ genotype. The data on reducing sugars of fruit was found to be non-significant for interaction effect of pruning time and various genotypes. However, highest reducing sugars of fruit $(5.46 \%)$ were noticed in $\mathrm{P}_{1} \mathrm{G}_{3}$ and minimum $(4.02 \%)$ in $\mathrm{P}_{5} \mathrm{G}_{1}$ treatment combinations in the pooled data. Results have been revealed that, improvement was observed in quality of guava fruit of pruned plants compared to control once. This might be due to increase nutrient uptake by the trees and consequently more synthesis of carbohydrates and other metabolites and their translocation to the fruits. The results are found similar with Nikumbhe (2014) [11] and Raut et al., (2016) ${ }^{[14]}$ reported that better quality of fruits observed in fruits of pruned guava plants compared to control plants. 
Table 3: Effect of pruning time and genotypes on reducing sugars $(\%)$ of fruit

\begin{tabular}{|c|c|c|c|c|c|c|c|c|}
\hline \multirow{3}{*}{$\begin{array}{c}\text { Treatments } \\
\begin{array}{c}\text { Pruning } \\
\text { time }\end{array}\end{array}$} & \multicolumn{8}{|c|}{$\begin{array}{l}\text { Reducing sugars of fruit (Pooled data of } 2 \text { years- } \\
\qquad 2016 \& 2017 \text { ) }\end{array}$} \\
\hline & \multicolumn{8}{|c|}{ Guava genotypes } \\
\hline & $\mathbf{G}_{1}$ & $\mathbf{G}_{2}$ & G3 & $\mathbf{G}_{4}$ & G5 & G6 & $\mathbf{G}_{7}$ & Mean \\
\hline $\mathrm{P}_{1}$ & 4.51 & 4.92 & 5.46 & 5.07 & 4.89 & 5.28 & 4.81 & 4.99 \\
\hline $\mathrm{P}_{2}$ & 4.46 & 4.62 & 5.26 & 4.87 & 4.75 & 5.03 & 4.6 & 4.80 \\
\hline $\mathrm{P}_{3}$ & 4.16 & 4.28 & 4.88 & 4.48 & 4.39 & 4.92 & 4.4 & 4.51 \\
\hline $\mathrm{P}_{4}$ & 4.22 & 4.38 & 4.82 & 4.52 & 4.52 & 4.67 & 4. & 4.46 \\
\hline $\mathrm{P}_{5}$ & 4.02 & 4.29 & 4.80 & 4.50 & 4.34 & 4.60 & 4.0 & 4.37 \\
\hline $\mathrm{P}_{6}($ Control $)$ & 4.29 & 4.49 & 5.24 & 4.69 & 4.52 & 5.11 & 4.59 & 4.70 \\
\hline Mean & 4.28 & 4.50 & 5.07 & 4.69 & 4.57 & 4.93 & 4.44 & 4.64 \\
\hline \multicolumn{2}{|c|}{ Year $2016 \& 2017$} & \multicolumn{2}{|c|}{$\begin{array}{l}\text { Pruning } \\
\text { time }\end{array}$} & \multicolumn{2}{|c|}{$\begin{array}{c}\text { Guava } \\
\text { genotypes }\end{array}$} & \multicolumn{3}{|c|}{ Interaction $(\mathrm{P} \times \mathrm{G})$} \\
\hline \multicolumn{2}{|c|}{$\mathrm{SE}(\mathrm{m}) \pm$} & \multicolumn{2}{|c|}{0.04} & \multicolumn{2}{|c|}{0.05} & \multicolumn{3}{|c|}{0.11} \\
\hline \multicolumn{2}{|l|}{ CD 5\% } & \multicolumn{2}{|c|}{0.12} & \multicolumn{2}{|c|}{0.13} & \\
\hline
\end{tabular}

\section{Non-reducing sugars $(\%)$ of fruit}

The data related to non-reducing sugars of guava fruit are displayed in Table 4. The maximum non-reducing sugars of fruit $(3.24 \%)$ were observed in $\mathrm{P}_{5}$ treatment and the minimum $(3.05 \%)$ in $\mathrm{P}_{1}$ treatment for pooled results. Effects of genotypes were found maximum $(3.25 \%)$ in $\mathrm{G}_{7}$ genotype and minimum $(3.00 \%)$ in $\mathrm{G}_{3}$ genotype. As regards interaction effects, the $\mathrm{P}_{5} \mathrm{G}_{7}$ treatment combination was noted maximum non-reducing sugars of fruit $(3.36 \%)$, whereas the minimum $(2.92 \%)$ in $\mathrm{P}_{1} \mathrm{G}_{3}$ treatment combination in pooled data. Overall considering the results indicated that, the maximum non-reducing sugars were recorded in $\mathrm{P}_{5}\left(15^{\text {th }}\right.$ September pruning time) treatment compared to other treatments. This might be due to the abundant availability of photosynthesis for limited number of fruits leads to increase in non-reducing sugars. The results coincided with findings of Nikumbhe (2014) ${ }^{[11]}$ in guava.

Table 4 Effect of pruning time and genotypes on non-reducing sugars $(\%)$ of fruit

\begin{tabular}{|c|c|c|c|c|c|c|c|c|}
\hline \multirow{3}{*}{$\begin{array}{c}\text { Treatments } \\
\begin{array}{c}\text { Pruning } \\
\text { time }\end{array}\end{array}$} & \multicolumn{8}{|c|}{$\begin{array}{c}\text { Non-reducing sugars of fruit (Pooled data of } 2 \\
\text { years- } 2016 \& 2017 \text { ) }\end{array}$} \\
\hline & \multicolumn{8}{|c|}{$\begin{array}{c}\text { Guava genotypes } \\
\end{array}$} \\
\hline & $\mathbf{G}_{1}$ & $\mathbf{G}_{2}$ & $\mathbf{G}_{3}$ & $\mathbf{G}_{4}$ & $\mathbf{G}_{5}$ & $\mathbf{G}_{6}$ & $\mathbf{G}_{7}$ & Mean \\
\hline $\mathrm{P}_{1}$ & 3.25 & 2.98 & 2.92 & 2.95 & 3.08 & 3.00 & 3.21 & 3.05 \\
\hline $\mathrm{P}_{2}$ & 3.17 & 3.05 & 2.95 & 3.00 & 3.07 & 3.11 & 3.23 & 3. \\
\hline $\mathrm{P}_{3}$ & 3.17 & 3.24 & 3.08 & 3.21 & 3.21 & 2.98 & & 3.15 \\
\hline $\mathrm{P}_{4}$ & 3.28 & 3.27 & 3.01 & 3.25 & 3.21 & 3.00 & 3.27 & 3.18 \\
\hline $\mathrm{P}_{5}$ & 3.29 & 3.31 & 3.14 & 3.27 & 3.16 & 3.13 & 3.36 & 3.24 \\
\hline $\mathrm{P}_{6}(\mathrm{Control})$ & 3.24 & 3.19 & 2.93 & 3.11 & 3.23 & 2.99 & 3.24 & 3.13 \\
\hline Mean & 3.23 & 3.17 & 3.00 & 3.13 & 3.16 & 3.03 & 3.25 & 3.14 \\
\hline \multicolumn{2}{|c|}{ Year 2016 \& 2017} & \multicolumn{2}{|c|}{ Pruning time } & \multicolumn{2}{|c|}{$\begin{array}{c}\text { Guava } \\
\text { genotypes }\end{array}$} & \multicolumn{3}{|c|}{ Interaction $(\mathrm{P} \times \mathrm{G})$} \\
\hline \multicolumn{2}{|c|}{$\mathrm{SE}(\mathrm{m}) \pm$} & \multicolumn{2}{|c|}{0.05} & \multicolumn{2}{|c|}{0.05} & \multicolumn{3}{|c|}{0.12} \\
\hline \multicolumn{2}{|l|}{ CD 5\% } & \multicolumn{2}{|c|}{$\mathrm{NS}$} & \multicolumn{2}{|c|}{0.14} & \multicolumn{3}{|c|}{ 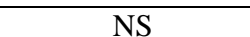 } \\
\hline
\end{tabular}

\section{Acidity (\%) of fruit}

The data in Table 5 related to the acidity of guava fruit was significantly influenced due to genotypes. This is very important biochemical parameter decides taste blend of guava. The pooled data of pruning time indicated that the minimum acidity of fruit $(0.37 \%)$ was noticed in $\mathrm{P}_{2}$ treatment, while the maximum $(0.40 \%)$ in $\mathrm{P}_{5}$ treatment. The data regarding effect of different genotypes on acidity of fruit was observed minimum acidity of fruit $(0.36 \%)$ in $\mathrm{G}_{3}$ genotype, which was at par with $\mathrm{G}_{2}, \mathrm{G}_{6}$ and $\mathrm{G}_{7}$ genotypes $(0.37 \%)$, while the maximum $(0.46 \%)$ in $\mathrm{G}_{1}$ genotype.

Table 5: Effect of pruning time and genotypes on acidity (\%) of fruit

\begin{tabular}{|c|c|c|c|c|c|c|c|c|}
\hline \multirow{3}{*}{$\begin{array}{c}\text { Treatments } \\
\begin{array}{c}\text { Pruning } \\
\text { time }\end{array}\end{array}$} & \multicolumn{8}{|c|}{$\begin{array}{l}\text { Acidity of fruit (Pooled data of } 2 \text { years- } 2016 \& \\
\text { 2017) }\end{array}$} \\
\hline & \multicolumn{8}{|c|}{$\begin{array}{l}\text { Guava genotypes } \\
\end{array}$} \\
\hline & $\mathbf{G}_{1}$ & $\mathbf{G}_{2}$ & $\mathbf{G}_{3}$ & $\mathbf{G}_{4}$ & G5 & $\mathbf{G}_{6}$ & $\mathbf{G}_{7}$ & Mean \\
\hline $\mathrm{P}_{1}$ & 0.47 & 0.36 & 0.36 & 0.39 & 0.40 & 0.36 & 0.36 & 0.39 \\
\hline $\mathrm{P}_{2}$ & 0.43 & 0.34 & 0.34 & 0.38 & 0.38 & 0.35 & 0.34 & 0.37 \\
\hline $\mathrm{P}_{3}$ & 0.46 & 0.36 & 0.37 & 0.39 & 0.39 & 0.37 & 0.39 & 0.39 \\
\hline $\mathrm{P}_{4}$ & 0.47 & 0.38 & 0.38 & 0.40 & 0.40 & 0.39 & 0.39 & 0.40 \\
\hline $\mathrm{P}_{5}$ & 0.48 & 0.39 & 0.38 & 0.41 & 0.40 & 0.39 & 0.39 & 0.40 \\
\hline $\mathrm{P}_{6}($ Control $)$ & 0.46 & 0.37 & 0.35 & 0.38 & 0.39 & 0.35 & 0.38 & 0.38 \\
\hline Mean & 0.46 & 0.37 & 0.36 & 0.39 & 0.39 & 0.37 & 0.37 & 0.39 \\
\hline \multicolumn{2}{|c|}{ Year 2016 \& 2017} & \multicolumn{2}{|c|}{$\begin{array}{l}\text { Pruning } \\
\text { time }\end{array}$} & \multicolumn{2}{|c|}{$\begin{array}{c}\text { Guava } \\
\text { genotypes }\end{array}$} & \multicolumn{3}{|c|}{ Interaction $(\mathrm{P} \times \mathrm{G})$} \\
\hline \multicolumn{2}{|c|}{$\mathrm{SE}(\mathrm{m}) \pm$} & \multicolumn{2}{|c|}{0.00} & \multicolumn{2}{|c|}{0.01} & \multicolumn{3}{|c|}{0.01} \\
\hline \multicolumn{2}{|l|}{ CD 5\% } & \multicolumn{2}{|c|}{ NS } & \multicolumn{2}{|c|}{0.01} & \multicolumn{3}{|c|}{ NS } \\
\hline
\end{tabular}

As regards, the data on interaction effect of treatment combinations indicated that, the maximum acidity of fruit $(0.48 \%)$ was noticed in $\mathrm{P}_{5} \mathrm{G}_{1}$ and minimum acidity in $\mathrm{P}_{2} \mathrm{G}_{2}$, $\mathrm{P}_{2} \mathrm{G}_{3}$ and $\mathrm{P}_{2} \mathrm{G}_{7}(0.34 \%)$ treatment combinations in pooled data. The present results observed that the pruning time does not affect too much on acidity but genotypes differ in acidity. It might be due to the independent characteristic of genotype along with pruning effect and also might be due to the abundant availability of photosynthesis for limited number of fruits leads to increase in acidity. Chandra and Govind (1995) ${ }^{[3]}$ reported similar results in guava that better quality of fruits observed in fruits of pruned guava plants compared to control.

\section{Ascorbic acid (mg/100 g) of fruit}

The data related to ascorbic acid of fruit are given in Table 6. Effect of pruning time reported that, the $\mathrm{P}_{2}$ treatment was recorded maximum ascorbic acid of fruit $(207.68 \mathrm{mg} / 100 \mathrm{~g})$ and the minimum $(190.84 \mathrm{mg} / 100 \mathrm{~g})$ was recorded in $\mathrm{P}_{5}$ treatment. As regarding effect of genotypes, significantly maximum ascorbic acid of fruit $(208.33 \mathrm{mg} / 100 \mathrm{~g})$ was observed in $G_{4}$ genotype, which was superior over rest of genotypes and minimum $(188.29 \mathrm{mg} / 100 \mathrm{~g})$ in $\mathrm{G}_{1}$ genotype.

Table 6: Effect of pruning time and genotypes on ascorbic acid (mg $/ 100 \mathrm{~g}$ ) of fruit

\begin{tabular}{|c|c|c|c|c|c|c|c|c|}
\hline \multirow{3}{*}{\begin{tabular}{|c|} 
Treatments \\
$\begin{array}{c}\text { Pruning } \\
\text { time }\end{array}$ \\
\end{tabular}} & \multicolumn{8}{|c|}{$\begin{array}{l}\text { Ascorbic acid of fruit (Pooled data of } 2 \text { years- } 2016 \\
\qquad \& 2017)\end{array}$} \\
\hline & \multicolumn{8}{|c|}{ Guava genotypes } \\
\hline & $\mathbf{G}_{\mathbf{1}}$ & $\mathbf{G}_{2}$ & $\mathbf{G}_{3}$ & $\mathbf{G}_{4}$ & $\mathbf{G}_{5}$ & G6 & $\mathbf{G}_{7}$ & Mean \\
\hline $\mathrm{P}_{1}$ & \multicolumn{8}{|c|}{\begin{tabular}{|l|l|l|l|l|l|l|l|l|l|l|l|l|}
191.25 & 198.25 & 201.25 & 210.50 & 204.25 & 201.00 & 194.25 & 200.11 \\
\end{tabular}} \\
\hline $\mathrm{P}_{2}$ & \multicolumn{8}{|c|}{ 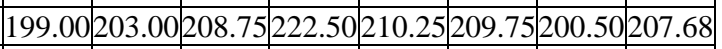 } \\
\hline $\mathrm{P}_{3}$ & \multicolumn{8}{|c|}{ 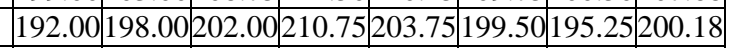 } \\
\hline 14 & \multicolumn{8}{|c|}{ 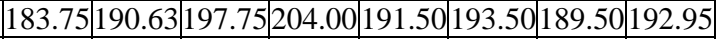 } \\
\hline $\mathrm{P}_{5}$ & \multicolumn{8}{|c|}{\begin{tabular}{|l|l|l|l|l|l|l|l|l|l|l|l|l|l|l|l|l|l|l|l|}
177.00 & 190.13 & 197.00 & 202.25 & 188.00 & 195.25 & 186.25 & 190.84 \\
\end{tabular}} \\
\hline $\mathrm{P}_{6}$ (Contr & \multicolumn{8}{|c|}{\begin{tabular}{|l|l|l|l|l|l|l|l|l|l|l|l|l|}
186.75 & 199.75 & 201.50 & 200.00 & 197.75 & 201.75 & 193.00 & 197.21 \\
\end{tabular}} \\
\hline & \multicolumn{8}{|c|}{\begin{tabular}{|l|l|l|l|l|l|l|l|}
188.29 & 196.63 & 201.38 & 208.33 & 199.25 & 200.13 & 193.13 & 198.16 \\
\end{tabular}} \\
\hline \multicolumn{2}{|c|}{ Year 2016 \& 2017} & \multicolumn{2}{|c|}{ Pruning time } & \multicolumn{2}{|c|}{$\begin{array}{l}\text { Guava } \\
\text { genotypes }\end{array}$} & \multicolumn{3}{|c|}{ Interaction $(\mathrm{P} \times \mathrm{G})$} \\
\hline \multicolumn{2}{|c|}{$\mathrm{SE}(\mathrm{m}) \pm$} & & \multicolumn{2}{|c|}{0.87} & \\
\hline \multicolumn{2}{|c|}{ CD 5\% } & & & & 42 & & 5.93 & \\
\hline
\end{tabular}

Interaction effect of different pruning time and genotypes was found to be statistically significant for ascorbic acid content. The highest ascorbic acid content $(222.50 \mathrm{mg} / 100 \mathrm{~g})$ was 
noticed in $\mathrm{P}_{2} \mathrm{G}_{4}$ and minimum $(177.00 \mathrm{mg} / 100 \mathrm{~g})$ in $\mathrm{P}_{5} \mathrm{G}_{1}$ treatment combinations. The results indicated that the maximum ascorbic acid content in fruit increased with pruning as compared to control ones. This might be due to the abundant availability of photosynthesis for limited number of fruits leads to increase in ascorbic acid. As well as prevalence of low temperature increases ascorbic acid in fruit The results are similar findings of Dubey et al. (2002) ${ }^{[4]}$, Prakash et al. (2012) ${ }^{[13]}$ and Mali et al. (2016) who registered the highest ascorbic acid content in fruits produced by trees subjected to severe pruning, also observed improved ascorbic acid content in fruits of guava after pruning.

\section{Sugar: acid ratio of fruit}

The data in respect to sugar: acid ratio of fruit is presented in Table 7. Significant differences in sugar: acid ratio of fruit was recorded due to effect of pruning time and genotypes. In pooled results, the maximum sugar: acid ratio of fruit (21.71) was noted in $\mathrm{P}_{2}$ treatment and minimum (18.99) in $\mathrm{P}_{5}$ treatment in pooled data. Data in respect to effect of different genotypes revealed that, significantly maximum sugar: acid ratio of fruit (22.33) was recorded in $\mathrm{G}_{3}$ genotype and minimum (16.38) in $\mathrm{G}_{1}$ genotype.The effect of various interactions between different pruning time and genotypes were found maximum sugar: acid ratio of fruit (24.17) in $\mathrm{P}_{2} \mathrm{G}_{3}$ treatment combination and minimum sugar: acid ratio (15.38) in $\mathrm{P}_{5} \mathrm{G}_{1}$ treatment combination.

Table 7: Effect of pruning time and genotypes on sugar: acid ratio of fruit

\begin{tabular}{|c|c|c|c|c|c|c|c|c|}
\hline \multirow{3}{*}{$\begin{array}{c}\text { Treatments } \\
\begin{array}{c}\text { Pruning } \\
\text { time }\end{array}\end{array}$} & \multicolumn{8}{|c|}{$\begin{array}{l}\text { Sugar: Acid ratio of fruit (Pooled data of } 2 \text { years- } \\
\qquad 2016 \& 2017)\end{array}$} \\
\hline & \multicolumn{8}{|c|}{ Guava genotypes } \\
\hline & G1 & $\mathbf{G}_{2}$ & $\mathbf{G}_{3}$ & $\mathbf{G}_{4}$ & G5 & G6 & $\mathbf{G}_{7}$ & Mean \\
\hline & 16.71 & 21.82 & 23.34 & 20.57 & 20.10 & 23.20 & 22.29 & 1.15 \\
\hline & 7.76 & 22.37 & & 20.72 & 20.50 & 49 & & \\
\hline & 5.07 & 20.81 & 21. & 20.01 & 19 & 21 & & \\
\hline & .88 & 20.4 & & 19 & & & & \\
\hline & 5.38 & 19.76 & & 19. & 18.89 & 19.71 & & \\
\hline$\overline{\mathrm{P}_{6}(\mathrm{Co}}$ & 16.48 & 21.09 & 23.24 & 20.54 & 20.15 & 23.35 & 20.88 & 20.82 \\
\hline & 16.38 & 21.05 & 22.33 & 20.07 & 19.74 & 21.83 & 20.62 & 20.29 \\
\hline \multicolumn{2}{|c|}{ Year 2016 \& 2017} & \multicolumn{2}{|c|}{ Pruning time } & \multicolumn{2}{|c|}{$\begin{array}{c}\text { Guava } \\
\text { genotypes }\end{array}$} & \multicolumn{3}{|c|}{ Interaction $(\mathrm{P} \times \mathrm{G})$} \\
\hline \multicolumn{2}{|c|}{$\mathrm{SE}(\mathrm{m}) \pm$} & \multicolumn{2}{|c|}{0.32} & \multicolumn{2}{|c|}{0.34} & \multicolumn{3}{|c|}{0.84} \\
\hline \multicolumn{2}{|c|}{ CD 5\% } & \multicolumn{2}{|c|}{0.88} & \multicolumn{2}{|c|}{0.95} & \multicolumn{3}{|c|}{ NS } \\
\hline
\end{tabular}

Overall considering the results revealed that, maximum sugar: acid ratio was noticed in pruned plants as compared to control plants of guava. This is might be due to healthy shoot canopy, better sun light distribution in canopy, better sun light utilization and better photosynthetic rate in pruned plants. Shirsath (2013) ${ }^{[17]}$ and Nikumbhe (2014) ${ }^{[11]}$ reported similar results that maximum sugar: acid ratio was recorded in pruned plants compared to control plants in guava.

\section{Shelf life of fruit (days)}

The data on shelf life of fruit are displayed in Table 8. The effect of pruning times and genotypes was found to be significant during both the years and pooled results for shelf life of fruit. Effect of pruning time indicated that, the maximum shelf life of fruit (8.44 days) was recorded in $\mathrm{P}_{1}$ treatment, which was at par with $\mathrm{P}_{2}$ treatment (8.30 days) and the minimum ( 7.13 days) in $\mathrm{P}_{5}$ treatment. Effect of genotypes revealed that, the $\mathrm{G}_{4}$ genotype was recorded significantly maximum shelf life of fruit (9.20 days), which was at par with
$\mathrm{G}_{3}$ genotype (9.11 days) and $\mathrm{G}_{6}$ genotype (9.09 days) while the minimum (3.57 days) in $\mathrm{G}_{1}$ genotype.

Table 8: Effect of pruning time and genotypes on shelf life of fruit (days)

\begin{tabular}{|c|c|c|c|c|c|c|c|c|}
\hline \multirow{3}{*}{\begin{tabular}{c|} 
Treatments \\
$\begin{array}{c}\text { Pruning } \\
\text { time }\end{array}$ \\
\end{tabular}} & \multicolumn{8}{|c|}{$\begin{array}{l}\text { Shelf life of fruit (Pooled data of } 2 \text { years- } 2016 \text { \& } \\
\text { 2017) }\end{array}$} \\
\hline & \multicolumn{8}{|c|}{\begin{tabular}{|c|} 
Guava genotypes \\
\end{tabular}} \\
\hline & $\mathbf{G}_{\mathbf{1}}$ & $\mathbf{G}_{2}$ & $\mathbf{G}_{3}$ & $\mathbf{G}_{4}$ & $\mathbf{G}_{5}$ & $\mathbf{G}_{6}$ & $\mathbf{G}_{7}$ & Mean \\
\hline $\mathrm{P}_{1}$ & 3.70 & 8.86 & 9.60 & 9.75 & 8.75 & 9.56 & 8.88 & 8.44 \\
\hline $\mathrm{P}_{2}$ & 3.60 & 8.72 & 9.53 & 9.63 & 8.58 & 9.51 & 8.55 & 8.30 \\
\hline $\mathrm{P}_{3}$ & 3.63 & 8.47 & 8.99 & 9.11 & 8.42 & 9.15 & 8.53 & 8.04 \\
\hline $\mathrm{P}_{4}$ & 3.53 & 8.11 & 9.01 & 9.08 & 8.19 & 9.01 & 8.14 & 7.87 \\
\hline$P_{5}$ & 3.28 & 7.36 & 8.12 & 8.11 & 7.41 & 7.84 & 7.80 & 7.13 \\
\hline $\mathrm{P}_{6}(\mathrm{Control})$ & 3.70 & 8.39 & 9.39 & 9.50 & 8.50 & 9.51 & 8.83 & 8.26 \\
\hline Mean & 3.57 & 8.32 & 9.11 & 9.20 & 8.31 & 9.09 & 8.45 & 8.01 \\
\hline \multicolumn{2}{|c|}{ Year 2016 \& 2017} & \multicolumn{2}{|c|}{$\begin{array}{l}\text { Pruning } \\
\text { time }\end{array}$} & \multicolumn{2}{|c|}{$\begin{array}{c}\text { Guava } \\
\text { genotypes }\end{array}$} & \multicolumn{3}{|c|}{ Interaction $(\mathrm{P} \times \mathrm{G})$} \\
\hline \multicolumn{2}{|c|}{$\mathrm{SE}(\mathrm{m}) \pm$} & \multicolumn{2}{|c|}{0.06} & \multicolumn{2}{|c|}{0.06} & \multicolumn{3}{|c|}{0.15} \\
\hline \multicolumn{2}{|l|}{ CD 5\% } & \multicolumn{2}{|c|}{016} & & & & 0.41 & \\
\hline
\end{tabular}

Regarding interactions effect of pruning time and genotypes, the $\mathrm{P}_{1} \mathrm{G}_{4}$ treatment was recorded maximum shelf life of fruit(9.75 days), which was at par with $\mathrm{P}_{2} \mathrm{G}_{4}$ (9.63 days), $\mathrm{P}_{1} \mathrm{G}_{3}$ (9.60 days), $\mathrm{P}_{1} \mathrm{G}_{6}$ (9.56 days), $\mathrm{P}_{2} \mathrm{G}_{3}$ (9.53 days), $\mathrm{P}_{2} \mathrm{G}_{6}$ (9.51 days), $\mathrm{P}_{6} \mathrm{G}_{6}$ (9.51 days), $\mathrm{P}_{6} \mathrm{G}_{4}$ (9.50 days) and $\mathrm{P}_{6} \mathrm{G}_{3}$ (9.39 days) treatment combinations and minimum in $\mathrm{P}_{5} \mathrm{G}_{1}$ (3.28 days) treatment combination. The results indicated that maximum shelf life of fruit was recorded in the pruning time of $15^{\text {th }}$ May $\left(\mathrm{P}_{1}\right)$ but later it was decreased from June to September pruning treatments and control. It might be due to slow rate of respiration of fruit due to which slow degradation of fruit taking place in low temperature. Nikumbhe (2014) [11] reported that maximum shelf life of fruit was recorded in $15^{\text {th }}$ May compared to other treatments in guava.

\section{Conclusion}

The results of present research it can be concluded that, the genotype RHR-Guv-60 is better in quality parameters like lustrous fruit, crispy pulp texture, maximum total sugars, reducing sugars and sugar acid ratio with minimum acidity thus it can be evaluated for cultivation as mrig bhar crop.

\section{Acknowledgement}

The authors are sincerely thankful to Department of Science $\&$ Technology, Ministry of Science \& Technology, Govt. of India, New Delhi for financial assistance during Ph.D. Program research.

\section{References}

1. Ali FS, Abdel-Hameed AA. Effect of pruning on yield and fruit quality of guava trees. Journal of Agriculture and Veterinary Science. 2014; 7(12):41-44.

2. AOAC Official method of analysis. Association of Official Agricultural Chemist $12^{\text {th }}$ Edn. Washington. DC, 1990, 564-596.

3. Chandra R, Govind S. Influence of time and intensity of pruning on growth, yield and fruit quality of guava under high density planting. Trop. Agric. (Trinidad). 1995; 72(2):110-113.

4. Dubey AK, Singh DB, Barche A, Meenakshi D. Deblossoming in summer season flowering in guava. Indian Horticulture. 2002; 47(1):35-36. 
5. Kumar Y, Rattanpal HS. Effect of pruning in guava planted at different spacing under Punjab conditions. Indian J of Hort. 2010; 67(Special issue):115-119.

6. Lane JH, Eynon L. General Volumetric Method of Sugar Analysis, AOAC, 1960, 426.

7. Mali DS, Ranpise SA, Kulkarni SS, Nikumbhe PH. Influence of pruning techniques on yield and fruit quality attributes in high density planting of guava cv Sardar. Eco. Env. \& Cons. 2016; 22(April Suppl.):S411-S414.

8. Menzel CM. Guava: An exotic fruit with potential in Queensland. Queensland Agri. J. 1985; 111:93-108.

9. Nagar PK, Satodiya BN, Dhaduk HL, Prajapati DG. Genetic variability and bio-chemical screening of guava (Psidium guajava L.) hybrids. International $\mathbf{J}$ of Chemical Studies. 2017; 5(6):143-146.

10. Nimisha S, Kherwar D, Ajay KM, Singh B, Usha K. Molecular breeding to improve guava (Psidium guajava L.): Current status and future prospective. Scientia Horticulturae. 2013; 164:578-588.

11. Nikumbhe PH. Standardization of pruning technique in guava (Psidium guajava L.) selection. Ph.D. Thesis Mahatma Phule Krishi Vidyapeeth, Rahuri, 2014.

12. Panse VG, Sukhatme PV. Statistical Methods of Agriculture Workers, $4^{\text {th }}$ Ed. ICAR, New Delhi Publication, 1985, 347.

13. Prakash S, Kumar V, Saroj PL, Sirohi SC. Response of yield and quality of winter guava to severity of summer pruning. Indian Journal of Horticulture. 2012; 69(2):173176.

14. Raut SA, Choudhary SM, Naglot UM, Chavan DL. Effect of time and intensity of pruning on yield and quality of guava (Psidium guajava L.) cv Sardar. Advances in Life Sciences. 2016; 5(22):10750-10752.

15. Ray PK. Breeding tropical and subtropical fruits. Narosa publishing house, New Delhi, 2002, 143-155.

16. Sheikh, MK, Hulmani, NC. Effect of severity of pruning on flowering and fruit quality of guava cv. Navalur. Prog. Hort. 1996; 25:157-160.

17. Shirsath HK. Studies on agro-techniques in guava (Psidium guajava L.) cv Sardar I. High density planting and II. Rejuvenation of old orchard. Ph.D. Thesis, Mahatma Phule Krishi Vidyapeeth, Rahuri, India, 2013.

18. Singh D. Morphological and molecular characterization of guava (Psidium guajava L.) germplasm and $\mathrm{F}_{1}$ hybrids. Ph.D. dissertation. Punjab Agricultural University, Ludhiana, India, 2013.

19. Singh G, Dhaliwal GS. Effect of different pruning levels on fruit yield and quality of guava cv Sardar. Haryana J of Hort. Sci. 2004; 33(1-2):83-84.

20. Singh $G$, Singh AK. Influence of pruning date on fruit quality of guava. J Appl. Horti. 2001; 3(2):100-102.

21. Singh G, Mishra R, Singh GP. Guava rejuvenation, Extension Bulletin-28 CISH Lucknow, 2005, 20.

22. Singh NK, Shivastava DC, Bhandarkar AP. Growth, yield and quality of guava as influenced by varying rejuvenation periods. Indian J Hort. 2012; 69(2):181-184. 